\title{
I Simpósio Gaúcho Sobre a Escravidão Negra
}

Nos dias 9-12 de outubro de 1990 realizou-se, no Curso de Pós-Graduação em História, da Pontifícia Universidade Católica do Rio Grande do Sul, o I Simpósio Gaúcho Sobre a Escravidão Negra. Na ocasião, foram apresentadas 41 comunicações sobre a história da escravidão brasileira, em geral, e da sulina, em especial. Participaram do Simpósio historiadores da Colômbia, do Uruguai, de Rondônia, do Maranhão, da Paraíba, de São Paulo, de Minas Gerais, do Paraná, de Santa Catarina e de diversos pontos do RS. Paralelo ao Simpósio, foi ministrado, dos dias 9 a 13 de outubro, um curso de extensão sobre "A Escravidão Negra do Rio Grande do Sul (1737-1888)", durante o qual especialistas no tema traçaram um amplo painel do escravismo sulino.

O primeiro encontro nacional sobre as raízes negras da civilização brasileira realizou-se, em 1934, em Recife. Três anos mais tarde, em Salvador, reunia-se o II Congresso Afro-Brasileiro da Bahia. Foi necessário que se passasse um século da Abolição e mais de 50 anos da ocorrência daqueles encontros para que algo semelhante fosse organizado no Sul. Apenas uma grande importância do passado escravista para as sociedades nordestinas e uma escassa influência na história sulina justificariam o atraso gaúcho em promover um evento que impulsionasse as pesquisas sobre o tema, especialmente as referentes à história do RS. Efetivamente, 24 comunicações inscritas ao Simpósio trataram de diferentes tópicos do escravismo gaúcho.

Choca-se com a verdade histórica a difundida visão do Rio Grande do Sul produto exclusivo do trabalho livre. Até a abolição da escravatura, em 1888, o Extremo Sul sempre se encontrou entre as principais capitanias e províncias escravistas. Em 1872, o primeiro censo nacional sobre a população servil revelou que o Rio Grande era a sexta provincia em quantidade absoluta de escravos, sendo superado apenas por Minas 
Gerais, Rio de Janeiro, São Paulo, Bahia e Pernambuco, centros da produção negreira nacional.

Segundo o levantamento demográfico de 1872 , Pernambuco possuía 106 mil cativos e a província gaúcha apenas 6 mil a menos. Quando do levantamento de 1884, mantinham-se aquelas posições. O historiador norte-americano Robert Conrad lembra, em Os Últimos Anos da Escravatura no Brasil, que, em 1888, quando a escravidão agonizava no Brasil e um importante movimento de emancipações condicionais varrera o RS, a província possuía ainda 8.500 escravos - "a maioria deles jovens e quase todos nas áreas rurais".

Tal foi a importância da escravidão no Sul que os representantes gaúchos no parlamento imperial constituíram, com seus pares das grandes províncias escravistas, uma verdadeira trincheira contra a reforma e abolição da instituição. Em 1871, os quatro deputados sulinos dividiram-se em torno do apoio à lei do "Ventre Livre" que, diga-se de passagem, não se destacava pelo radicalismo. Um dos dois deputados a votar contra a lei foi o Dr. Ildefonso Simões Lopes, oriundo da família de charqueadores pelotenses que teve como mais insigne filho o escritor Simões Lopes Neto.

A documentação histórica é cabal. O homem negro esteve presente no Sul desde a fundação da Colônia do Sacramento. Antes, portanto, da ocupação do Estreito e da fundação, em 1737, da vila de Rio Grande. A documentação coeva comprova a presença de escravarias na construção das vilas e povoações; nas primeiras plantações de trigo; nas atividades pastoris, etc. Foram as dificuldades de transporte e conservação das carnes dos gados sulinos que deram origem à importante atividade charqueadora, verdadeiro coração do escravismo sulino.

A indústria saladeiril viabilizou a economia pastoril e forneceu os capitais necessários à introdução de grandes quantidades de escravos novos trazidos das costas da África. Até a Abolição, fortes contingentes de trabalhadores servis labutaram incessantemente nas duras atividades da produção charqueadora. Nas charqueadas de Pelotas, principal pólo saladeiril, trabalhavam, muitas vezes, mais de 100 cativos. Boa parte das comunicações sulinas do I Simpósio Gaúcho Sobre a Escravidão Negra refere-se à Pelotas e à sua atividade charqueadora.

O mito da formação do Rio Grande do Sul sem a contribuição do braço escravo deve-se a historiadores que, desconhecendo a verdade 
documental, construíram uma visão idealizada do passado. "Para o Sul do Brasil [...] - escreveu o Gen. João Borges Fortes, em Os Casais Açorianos - não era bastante atirar naquelas terras os negros broncos dos resgates da África [...]. Viamo-nos, assim, libertados, quer da mácula dos degredados, quer da chaga da escravatura [...]. Podemos os descen-dentes dos casais regozijar-nos dos ancestrais de nossa raça, límpida nas suas origens."

Manoelito de Ornellas escreveu, no mesmo sentido, em Gaúchos e Beduínos: "O Rio Grande nascia do impulso desbravador de três correntes humanas, diferentes nos seus propósitos mas semelhantes nas suas origens raciais." Elas seriam o índio, o espanhol e o paulista. O mito da democracia sulina é filho desta produção historiográfica. Nosso Estado não teria conhecido contradições sociais quando de sua formação. "Pela natural independência do gaúcho - escreveu João Sales Goulart em $A$ Formação do Rio Grande do Sul -, não encontramos aqui nenhuma servidão econômica. Neste particular patrões e empregados [...] viviam em comum, com os mesmos hábitos e as mesmas necessidades."

Para que vingasse esta leitura, era necessário que se apagasse do imaginário histórico sulino a memória da escravidão. E, em grandíssima parte, ela foi esquecida. O trabalhador escravizado foi borrado da história gaúcha. Quando o grande pintor italiano Aldo Locatelli pintou, no Palácio Piratini, seu magnífico mural alegórico sobre as etnias fundadoras do Rio Grande, nele não houve espaço para o registro do esforço sofrido da mulher e do homem negro feitorizado.

A visão do Rio Grande do Sul livre do trabalho escravo falseia a verdade histórica, direito de toda a população sulina, e contribui à permanência de difundidos preconceitos raciais e sociais. Nega-se à comunidade afro-gaúcha o orgulho de ter contribuído sobremaneira, com o trabalho duro e impessoal do cativo, à fundação e ao desenvolvimento do RS. De um desenvolvimento do qual - diga-se de passagem - esta comunidade viveu e vive, em grande parte, à margem, apesar de ter sido e ainda ser um dos seus principais construtores.

Os primeiros golpes contra esta verdadeira mistificação histórica foram lançados por pesquisadores como Dante de Laytano e outros que mostraram a forte presença negra nos primeiros "mapas demográficos" e nas descrições dos viajantes que percorreram o Rio Grande, no início do século XIX. Após estes trabalhos pioneiros, cientistas sociais como 
Fernando Henrique Cardoso, Margaret Bakos, Berenice Corsetti, Décio Freitas, Moacyr Flores, Mário Maestri, Helga Picollo, Sandra J. Pesavento, Gunter Weimer, entre outros, têm corrigido aquelas visões impressionistas.

Entretanto, estes trabalhos apenas solapam a visão - quase oficial - do Rio Grande do Sul 'Província Branca'. Tal visão, tida como científica, é difundida pelos meios de comunicação, manuais escolares, literatura histórica, programas culturais, etc. O I Simpósio Gaúcho Sobre a Escravidão Negra procurou contribuir para que seja dado, em nosso Estado, um salto de qualidade nos estudos historiográficos sobre o passado escravista nacional, em geral, e gaúcho, em especial, criando-se assim as condições para a superação da verdadeira ausência de uma história do trabalhador escravizado no Brasil Meridional.

Por problemas editoriais, não foi possível publicar a totalidade dos trabalhos apresentados ao Simpósio neste número especial da Revista de Estudos Ibero-Americanos. A excelência dos trabalhos que seguem é testemunha da pertinência e do sucesso do evento.

Não teria sido possível a realização do I Simpósio Gaúcho Sobre a Escravidão Negra sem o apoio da Secretaria de Cultura do Estado do Rio Grande do Sul, da Fundação Gaúcha de Amparo a Pesquisa (FAPERGS) e das Pró-Reitorias de Pós-Graduação e Pesquisa e de Extensão da PUCRS. Fica aqui registrado igualmente o apoio acordado à organização do evento pelo Prof. Dr. Braz Brancato, Coordenador do Curso de Pós-Graduação em História e pela Profa. Dra. Margaret Bakos, da Universidade Federal do Rio Grande do Sul, que participou, desde os primeiros momentos, da organização do encontro.

\section{MÁRIO MAESTRI}

Curso de Pós-Graduação em História

Pontifícia Universidade Católica do RS 